\title{
A Chromosome Arm Number Index and Its Application to the Phylogeny and Classification of Lemurs
}

\author{
ROBERT B. ECKHARDT 1 \\ Departments of Anthropology and Human Genetics, \\ The University of Michigan, Ann Arbor, Michigan
}

\begin{abstract}
A method is described for assessing the degree to which chromosome evolution via centric fusion has occurred within a taxonomic group, using a numerical index which expresses the average number of major chromosome arms per chromosome in a diploid cell. Index values thus calculated agree with a previously proposed plan of prosimian phylogeny, and substantiate some recently suggested changes in taxonomic groups of the Lemurs, based on karyotypic evidence.
\end{abstract}

The evolution of the Primates has proceeded by means of a series of adaptations to arboreal and terrestrial ways of life. These adaptations have included changes in behavior and morphology. Accompanying these obvious changes have been less evident, but presumably nonetheless important, alterations in the number and morphology of chromosomes.

Several authors (Chu and Bender, '62; Hamerton, '63) have noted that within the Primates, and especially among the prosimians, species with a high diploid chromosome number have a high number of acrocentric chromosomes, while those with a lower diploid chromosome number have relatively fewer acrocentric and more metacentric chromosomes. These authors have suggested that a major form of karyotype evolution in the Primates has been of the Robertsonian type of centric fusion (Robertson, '16); that is, reciprocal translocations between two acrocentric chromosomes (with 1 major arm) result in the formation of a new metacentric chromosome (with two major arms), plus a chromosome which contains little genetic material and may presumably sometimes be lost without serious detriment to the organism. This could lead to a balanced chromosome polymorphism, as has already been found for at least one population of wild mammals, the common shrew (Ford et al., '57). The new karyotype could become fixed if the animals bearing it enjoyed some selective advantage, either due to the change or coincidental to it.
Judgment of whether such a process has occurred within a taxonomic group de pends on a consideration primarily of two measures: the NF or "nombre fondamental," which is the total number of major chromosome arms in a diploid cell (Matthey, '55); and the diploid, or $2 \mathrm{~N}$, chromosome number.

It is possible to combine both of these into a single measure, or index, the values of which will express the extent to which chromosome evolution via centric fusion has affected the karyotypes of the species within the group. This might be designated an "Arm Number Index" the values of which are obtained by dividing the number of major chromosome arms by the diploid chromosome number. The values obtained will give the average number of major chromosome arms per chromosome; they will range from 1.0, for species with all acrocentric chromosomes, to 2.0 , for species with all metacentric chromosomes.

That is,

$$
\begin{array}{r}
\text { Arm Number Index }=\frac{\mathrm{NF}}{2 \mathrm{~N}}, \\
\text { where } 1.0 \leq \mathrm{AAI} \leq 2.0 .
\end{array}
$$

The index described here does provide values which are entirely consistent with Chu and Bender's ('62) scheme of prosimian phylogeny based on the evolution of karyotypes, as may be seen from the material summarized in table 1 . Where results reported by different investigators do not agree, both determinations have

1 The support of NIH training grant 5-T01-GM71-11 is gratefully acknowledged. 
TABLE 1

\begin{tabular}{|c|c|c|c|c|c|c|c|c|c|c|}
\hline \multirow{3}{*}{ Species } & \multirow{3}{*}{$\begin{array}{c}\text { Common } \\
\text { name }\end{array}$} & \multirow{3}{*}{$2 \mathrm{~N}$} & \multicolumn{5}{|c|}{ Chromosomes 1} & \multirow{3}{*}{ NF 2} & \multirow{3}{*}{$\frac{N F}{2 N}$} & \multirow{3}{*}{ Reference } \\
\hline & & & \multicolumn{5}{|c|}{ Autosomal Sex } & & & \\
\hline & & & $\mathbf{M}$ & $\mathbf{s}$ & $\mathbf{A}$ & $\mathbf{x}$ & $\mathbf{Y}$ & & & \\
\hline \multirow{2}{*}{$\begin{array}{c}\text { Microcebus } \\
\text { murinus }\end{array}$} & \multicolumn{2}{|c|}{ Miller's mouse } & & & & & & & & \\
\hline & lemur & 66 & 0 & 2 & 64 & - & - & 68 & 1.03 & Chu and Bender, '61 \\
\hline \multirow{2}{*}{$\begin{array}{l}\text { Cheirogaleus } \\
\text { major }\end{array}$} & Dwarf & & & & & & & & & \\
\hline & & bo & 一 & 一 & 04 & - & - & 68 & 1.03 & Chu and Bender, 61 \\
\hline \multirow{2}{*}{$\begin{array}{l}\text { Hapalemur } \\
\text { griseus griseus }\end{array}$} & Gray gentle & & & & & & & & & \\
\hline & & 54 & 4 & $\mathbf{b}$ & 42 & $\mathbf{A}$ & $A$ & 64 & 1.19 & Bender and Cnu, os \\
\hline \multirow{2}{*}{\multicolumn{2}{|c|}{$\begin{array}{l}\text { H. griseus } \\
\text { olivaceus }\end{array}$}} & & & & & & & & & \\
\hline & & 58 & 2 & 4 & 52 & 一 & - & 64 & 1.10 & Bender and Chu, ' 63 \\
\hline \multirow[t]{2}{*}{ Lemur catta } & Ringtail & & & & & & & & & \\
\hline & lemur & 56 & 6 & 4 & 44 & $\mathbf{A}$ & A & 66 & 1.18 & Bender and Chu, '63 \\
\hline \multirow[t]{2}{*}{ L. catta } & Ringtail & & & & & & & & & \\
\hline & lemur & 56 & 8 & 6 & 40 & $\mathbf{A}$ & A & 70 & 1.25 & Egozcue, '67 \\
\hline \multirow[t]{2}{*}{ L. mongoz } & Mongoose & & & & & & & & & \\
\hline & lemur & 60 & 0 & 4 & 54 & $\mathbf{A}$ & $\mathbf{A}$ & 64 & 1.07 & Bender and Chu, '63 \\
\hline \multirow[t]{2}{*}{ L. mongoz } & Mongoose & & & & & & & & & \\
\hline & lemur & 58 & 0 & 4 & 52 & $\mathbf{A}$ & $\mathbf{A}$ & 62 & 1.07 & Egozcue, ,67 \\
\hline \multirow[t]{2}{*}{ L. fulvus rufus } & Red fronted & & & & & & & & 107 & 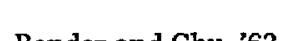 \\
\hline & & bu & 0 & 4 & 34 & $\mathbf{A}$ & $\mathbf{A}$ & 64 & 1.01 & Bender and Cnu, os \\
\hline \multirow{2}{*}{$\begin{array}{l}\text { L. fulvus } \\
\text { albifrons }\end{array}$} & White-fronter & & & & & & & & & \\
\hline & lemur & 60 & 0 & 4 & 54 & $\mathbf{A}$ & A & 64 & 1.07 & Bender and Chu, '63 \\
\hline \multirow[t]{2}{*}{ L. fulvus fulvus } & Brown & & & & & & & & & \\
\hline & lemur & 58 & 0 & 4 & $\mathbf{5 2}$ & A & $\mathbf{A}$ & 62 & 1.07 & Egozcue, '67 \\
\hline \multirow[t]{2}{*}{ L. fulvus fulvus } & Brown & & & & & & & & & \\
\hline & & 48 & 10 & 6 & 30 & $\mathbf{A}$ & $\mathbf{A}$ & 64 & 1.33 & Bender and Chu, 63 \\
\hline L. variegatus & Ruffed & 16 & 14 & 4 & 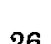 & $\mathrm{M}$ & & 66 & 143 & Bender and Chu '63 \\
\hline \multirow{2}{*}{ L. macaco } & Black & & & & & & & & & \\
\hline & lemur & 44 & 12 & 8 & 22 & $\mathbf{A}$ & A & 64 & 1.45 & Bender and Chu, '63 \\
\hline \multicolumn{2}{|l|}{ L. sp. nov. } & 52 & 8 & 4 & 38 & $\mathbf{M}$ & $A$ & 66 & 1.18 & Bender and Chu, '63 \\
\hline
\end{tabular}

1 Because of the variability in arm length it is sometimes difficult to designate a particular chromosome as $M$ (metacentric) or $S$ (subterminal), or $S$ or $A$ (acrocentric). The classification made in the original refer-

ence cited is used here, $X$ and $Y$ chromosomes have different numbers of arms, the number of arms found in the female has been used here.

been shown. If karyotype evolution has proceeded as Chu and Bender proposed, one would expect the values of the index described here to increase as the $2 \mathrm{~N}$ chromosome number decreases; as shown in figure 1 , they do without exception.

It has been suggested (Chu and Swomley, '61; Bender and Chu, '63) that the Lemurinae, on the basis of their karyotypes, fall into three natural groups, with the Hapalemurs comprising the first group; the second includes Lemur catta, L. mongoz, L. fulvus rufus and $L$. fulvus albifroms; and the third group is composed of $L$. fulvus fulvus, L. variegatus, L. macaco, plus an animal morphologically similar to L. fulvus fulvus but differing karyotypically, with a $2 \mathrm{~N}$ chromosome number of 52. (This animal was originally referred to by Chu and Swomley as Lemur sp. nov.) These authors noted that the three divisions were tentative, and that relationships could be traced both within and between the divisions.

Recently Egozcue ('67) has suggested some rearrangements of these groups. 


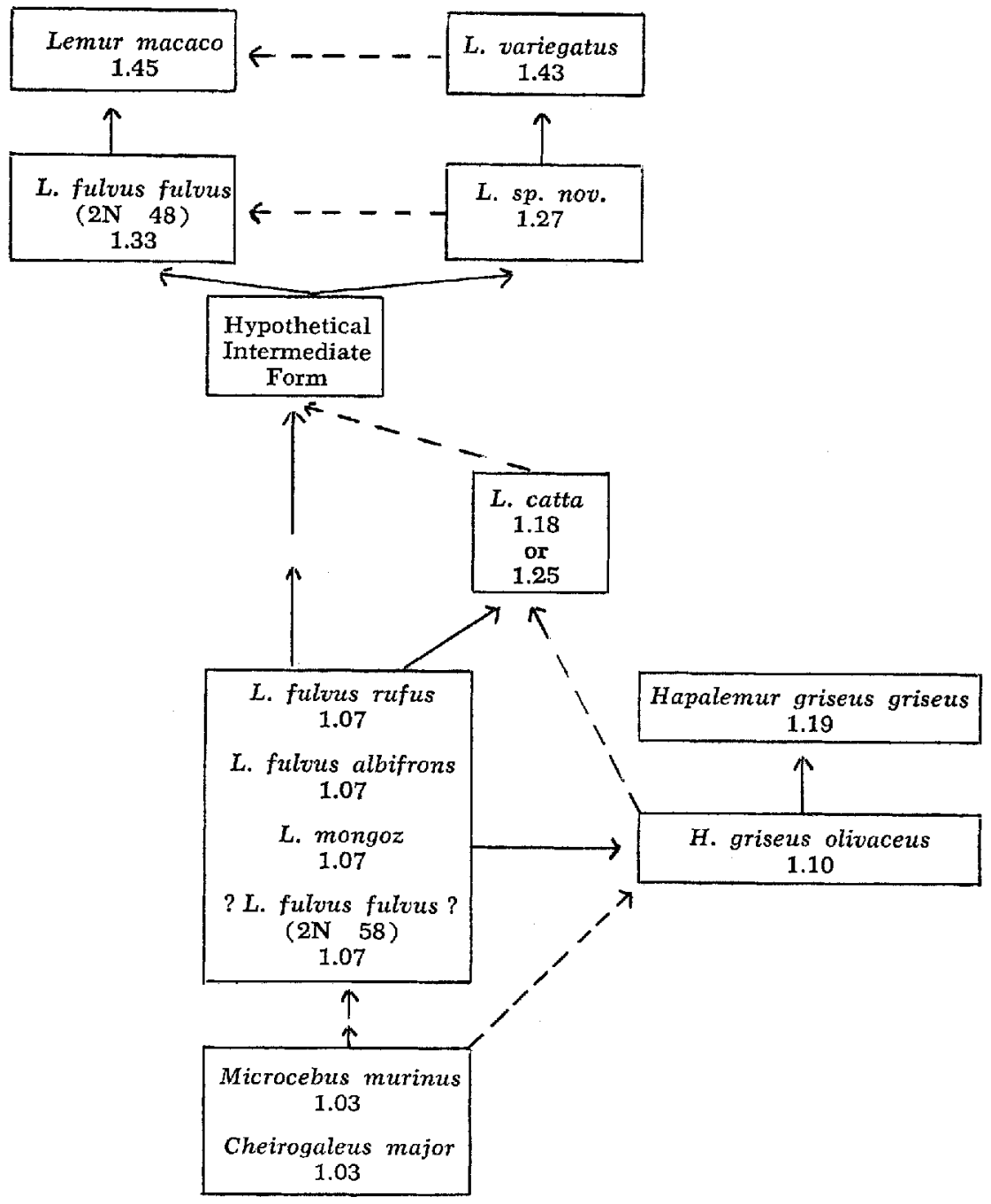

Fig. 1 Lemur phylogeny, with arm number index values.

These involved placing $L$. catta with the Hapalemurs, and combining those specimens of L. fulvus fulvus having a diploid number of 58 with $L$. fulvus albifrons, $L$. fulvus rufus, and L. mongoz. Those specimens of $L$. fulvus fulvus having a diploid number of 48 were left with $L$. variegatus and $L$. macaco (see table 2 for a comparison of the groupings).

Table 2 also shows that index values calculated as described in this paper lend some support for these modifications suggested by Egozcue, as they lead to more consistent values within the groups.
It should be noted, however, that acceptance of the changes suggested does not necessitate revision of Chu and Bender's scheme of prosimian phylogeny based on the analysis of karyotypes, since in this L. catta occupied an intermediate position among the groups, and could have been derived from either the $L$. mongoz $-L$. fulvus group or from the Hapalemurs, and served as a form plausibly ancestral to the third group which includes $L$. macaco, $L$. variegatus, L. fulvus fulvus with $2 \mathrm{~N}$ of 48 , and $L . s p$. nov. 
TABLE 2

Groups within the Lemurinae, based on analysis of karyotypes

\begin{tabular}{|c|c|c|c|}
\hline Chu and Swomley ('61) & $2 N$ & $\begin{array}{c}\text { Arm } \\
\text { number } \\
\text { index }\end{array}$ & Egozcue ('67) \\
\hline $\begin{array}{l}\text { Hapalemur griseus griseus } \\
\text { H. griseus olivaceus }\end{array}$ & $\begin{array}{l}52 \\
54 \\
58 \\
56\end{array}$ & $\begin{array}{l}1.27 \\
1.19 \\
1.10 \\
1.25\end{array}$ & $\begin{array}{l}\text { Lemur sp. nov. (tentative) } \\
\text { Hapalemur griseus griseus } \\
\text { H. griseus olivaceus } \\
\text { Lemur catta }\end{array}$ \\
\hline $\begin{array}{l}\text { Lemur catta } \\
\text { L. mongoz } \\
\text { L. fulvus rufus } \\
\text { L. fulvus albifrons }\end{array}$ & $\begin{array}{l}56 \\
60 \\
58 \\
60 \\
60 \\
58 \\
\end{array}$ & $\begin{array}{l}1.18 \\
1.07 \\
1.07 \\
1.07 \\
1.07 \\
1.07\end{array}$ & $\begin{array}{l}\text { L. mongoz } \\
\text { L. fulvus rufus } \\
\text { L. fulvus albifrons } \\
\text { L. fulvus fulvus }\end{array}$ \\
\hline $\begin{array}{l}\text { L. fulvus fulvus } \\
\text { L. variegatus } \\
\text { L. macaco } \\
\text { L. sp. nov. }\end{array}$ & $\begin{array}{l}48 \\
46 \\
44 \\
52\end{array}$ & $\begin{array}{l}1.33 \\
1.43 \\
1.45 \\
1.27\end{array}$ & $\begin{array}{l}\text { L. fulvus fulvus } \\
\text { L. variegatus } \\
\text { L. macaco }\end{array}$ \\
\hline
\end{tabular}

In cases such as this, where a Robertsonian type of chromosome evolution has occurred within a taxonomic group, there will be a decrease in the diploid chromosome number and in the number of acrocentric chromosomes from one species (or group of species) to the next, accompanied by an increase in the number of metacentrics. The NF should nevertheless remain constant throughout the group, unless obscured by other modifications. The index described here summarizes these trends and expresses in a convenient form a relationship between the $\mathrm{NF}$ and $2 \mathrm{~N}$ values which appears to be phylogenetically meaningful.

\section{LITERATURE CITED}

Bender, M. A., and E. H. Y. Chu 1963 The Chromosomes of the Primates. In: Evolutionary and Genetic Biology of Primates. Ed. J.
Buettner-Janusch. Vol. 1. Academic Press, New York.

Chu, E. H. Y., and M. A. Bender 1962 Cytogenetics and evolution of Primates. Ann. N. Y. Acad. Sci., 102; 253-266.

Chu, E. H. Y., and B. A. Swomley 1961 Chromosomes of lemurine lemurs. Science, 133: 1925-1926.

Egozcue, J. 1967 Chromosome variability in the lemuridae. Am. J. Phys. Anthrop., 26: 341348.

Ford, C. E., J. L. Hamerton and G. B. Sharman 1957 Chromosome polymorphism in the com. mon shrew. Nature, 180: 392-393.

Hamerton, J. L. 1963 Primate chromosomes. Symp. Zool. Soc. Lond., 10: 211.

Matthey, R. 1955 Les chromosomes de Galago senegalensis Geoffroy (Prosimii-LorisidaeMuridae). Rev. suisse Zool., 62 (suppl.): 190197.

Robertson, W. R. B. 1916 Chromosome studies. I. Taxonomic relationships shown in the chromosomes of Tettigidae and Acrididae. Vshaped chromosomes, their significance in Acrididae, Locustidae and Gryllidae: chromosomes and variation. J. Morph., 27: 179-331. 